\title{
Genistein, the Isoflavone in Soybean, Causes Amyloid Beta Peptide Accumulation in Human Neuroblastoma Cell Line: Implications in Alzheimer's Disease.
}

\author{
Gargi Chatterjee, Debashree Roy, Vineet Kumar Khemka, Mrittika Chattopadhyay, Sasanka \\ Chakrabarti*
}

Department of Biochemistry, Institute of Post Graduate Medical Education and Research, 244 AJC Bose Road, Kolkata-700020, India.

[Received February 18, 2015; Revised March 23, 2015; Accepted March 27, 2015]

\begin{abstract}
The isoflavone, genistein, present in soybean is being actively investigated for its potential beneficial effect against Alzheimer's disease. Our data, however, show that in SHSY5Y cells genistein causes increased expression (mRNA and protein) of amyloid precursor protein (APP), increased mRNA expression and activity of $\beta$-secretase and diminished level of insulin degrading enzyme (IDE) which also degrades amyloid beta peptide. These effects of genistein lead to enhanced accumulation of amyloid beta peptide (Aß42) in SHSY5Y cells. The results do not support the view that genistein could be a putative drug against AD and instead strengthen the epidemiological study which implies that genistein content of soybean food product (Tofu) leads to cognitive impairment.
\end{abstract}

Key words: Alzheimer's disease, genistein, amyloid precursor protein, $\beta$-secretase, insulin degrading enzyme, amyloid $\beta 42$.

Genistein is an isoflavone and phytoestrogen present in significant amount in soybean which is extensively used as a dietary source of protein across the globe [1]. There is a persistent campaign for the potential beneficial effects of soybean or soy products because of the presence of various isoflavones including genistein in this foodstuff [2]. In cell culture systems, genistein has been shown to prevent the proliferation of breast cancer cells (at higher concentrations) or to induce apoptosis in bcl-2 knockdown neuroblastoma cells or to promote osteoblastic bone formation and mineralization in cultured bone tissue [3, 4, 5]. In clinical trial earlier genistein has been shown to reduce serum total and LDL (low density lipoproten) cholesterol levels, though this could not be verified in subsequent studies [6]. In other studies in experimental animals, genistein has been shown to prevent the impairment of memory and cognition induced by intracerebroventricular administration of amyloid beta peptide (A 340$)$ or streptozotocin [7, 8]. Further, amyloid beta peptide induced inflammatory response of astrocytes in culture or the death of cultured SHSY5Y cells, human neuroblastoma cell line, could be blocked by genistein $[9$, 10]. Genistein also has been shown to ameliorate the astrogliosis in hippocampus of rats following injection of amyloid beta [11]. Likewise, A $\beta 25-35$ induced apoptosis of hippocampal cells is prevented by genistein [12]. Based on such experimental studies and the structural similarity of genistein with estrogen, a hormone with neuroprotective functions in different experimental models, a clinical trial of genistein against AD has been initiated which is likely to be completed in September 2015 [13]. In contrast, the Honululu-Asia Aging Study

*Correspondence should be addressed to: Dr. Sasanka Chakrabarti, Department of Biochemistry, Institute of Post Graduate Medical Education and Research, Kolkata-700020, India. Email: profschakrabarti95@gmail.com 
has reported that mid-life high intake of Tofu (soybean curd) is associated with increased risk of dementia which could be attributed to high content of isoflavones, in particular genistein, in Tofu [14]. Another cross-sectional study in Indonesia has also linked poor memory performance with high Tofu intake [15]. Thus, the potential beneficial effect of genistein against $\mathrm{AD}$ is somewhat questionable. Moreover, genistein has multiple actions at the cellular level such as tyrosine kinase inhibition, inhibition of topoisomerase, inhibition of cell proliferation or induction of apoptosis, activation of PPARy etc. which can impact AD pathogenesis in more than one ways $[4,16,17,18]$. In order to explore this problem further, we have examined how genistein might affect the various aspects of amyloid beta metabolism employing SHSY5Y human neuroblastoma cell line. SHSY5Y cells have been used extensively to study amyloid precursor protein (APP) expression, processing and trafficking and amyloid beta peptide homeostasis within cells, and further these cells, both undifferentiated or differentiated by retinoic acid treatment, serve as a useful tool for elucidation of the pathways of neurodegeneration induced by various toxic agents including amyloid beta [19, 20,21].

\section{MATERIALS AND METHODS}

\section{Materials}

All cell culture media, supplements, and fetal bovine serum (FBS) were obtained from Thermo Scientific Hyclone (Logan, USA). Genistein was obtained from Calbiochem (San Diego, USA). All electrophoresis reagents were obtained from Sisco Research Laboratory (Mumbai, India). Beta-amyloid [1-16] antibody was obtained from ABBIOTECH (San Diego, USA). Lyophilized powders of pure A $\beta 42$ was obtained from Anaspec (Fremont, USA), Anti-amyloid precursor protein antibody, N-dansyl-Ala-Gly-D-nitro-Phe-Gly, DL-thiorphan, hexafluoro-2-propanol (HFIP), protease inhibitor cocktail, phenylmethanesulfonyl fluoride (PMSF), deoxycholate, sodium dodecyl sulfate (SDS), NP-40 were from Sigma Aldrich Chemical Co. (St. Louis, USA), and anti-IDE antibody was from Santa Cruz Biotech, Inc. (Dallas, USA). All secondary antibodyhorse radish peroxidase conjugates were purchased from Bangalore Genei Pvt. Ltd (Bangaluru, India). $\beta$-secretase assay kit was purchased from BioVision, Inc. (Milpitas, USA). A $\beta 42$ human elisa kit was purchased from Invitrogen (Life Technologies, Inc., Paisley, U.K.). Bicinchoninic acid (BCA) protein assay kit was from Pierce (Rockford, IL, USA). RNA isolation kit was purchased from Ambion (Life Technologies, Inc., Paisley, U.K.). All reagents required for RT-qPCR (iScript cDNA synthesis kit, $\mathrm{iQ}^{\mathrm{TM}} \mathrm{SYBR}^{\circledR} \mathrm{Green}$ Supermix) were obtained from Bio-Rad Laboratories, Inc. (Berkeley, USA). Primers were obtained from Metabion (Steinkirchen, Germany). All common reagents were of analytical or molecular biology grade.

\section{Cell culture and experimental treatments}

Human neuroblastoma cell line SHSY5Y used in this study was obtained from ATCC (American Type Culture Collection, USA). Cells were cultured in Dulbecco's Modified Eagle Medium (DMEM) and F12 HAM mixed in $1: 1$ ratio and supplemented with $10 \%$ fetal bovine serum and 100 units $/ \mathrm{ml}$ penicillin, $100 \mu \mathrm{g} / \mathrm{ml}$ streptomycin, $0.25 \mu \mathrm{g} / \mathrm{ml}$ amphotericine $\mathrm{B}$, at $37^{\circ} \mathrm{C}$ in a humid atmosphere of $5 \% \quad \mathrm{CO}_{2}$ and $95 \%$ air. For experimental purposes, $1 \times 10^{6}$ cells were seeded on $25 \mathrm{~cm}^{2}$ flask or $0.2 \times 10^{6}$ cells on 12 well plates (for $\beta$-secretase assay). Cells (60 - $70 \%$ confluent) were incubated for 48 $\mathrm{h}$ without (control) or with different concentrations of genistein $(10,20$ and $30 \mu \mathrm{M})$

\section{Preparation of cell lysate}

For immunoblotting of APP, the cells were homogenized using a cell disruptor (IKA laboratory equipments, T-10 basic) in a buffer (225 mM mannitol, $75 \mathrm{mM}$ sucrose, 5 $\mathrm{mM}$ HEPES, $1 \mathrm{mM}$ EGTA, $1 \mathrm{mg} / \mathrm{ml}$ BSA, $\mathrm{pH}$ 7.4) containing protease inhibitor cocktail followed by centrifugation at $2000 \mathrm{Xg}$ for $3 \mathrm{~min}$. The supernatant was further centrifuged at $1,00,000 \mathrm{Xg}$ for $1 \mathrm{~h}$ at $4^{\circ} \mathrm{C}$ and the pellet re-suspended in the lysis buffer A $(50 \mathrm{mM}$ Tris $\mathrm{pH}$ 8.0, $150 \mathrm{mM} \mathrm{NaCl}, 5 \mathrm{mM}$ EDTA, 1\% SDS, $0.5 \%$ deoxycholate, $0.5 \%$ NP-40) and used for immunoblotting. For immunodetection of $A \beta 42$, the cell lysate was prepared by sonication in the lysis buffer A. The supernatant was used for immunoblotting. For detection of IDE by immuno-blotting, the cell extract was prepared by using a lysis buffer containing $50 \mathrm{mM}$ Tris- $\mathrm{HCl}, \mathrm{pH}$ $7.4,50 \mathrm{mM} \mathrm{NaCl}$ and $1 \%$ Triton X100 supplemented with PMSF and a protease inhibitor cocktail [22].

\section{Immunodetection of proteins}

For immunodetection, the cell lysate proteins $(20-40 \mu \mathrm{g})$ were separated by sodium dodecyl sulphate polyacrylamide gel electrophoresis (SDS-PAGE) on a $10 \%$ resolving gel, transferred to a nitrocellulose membrane and processed as per standard blotting protocols [23]. Each sample was adjusted to the same protein concentration in a particular set. The primary antibodies were used in appropriate dilutions (for APP, 1:2000; for $A \beta 42,1: 2000$; for IDE, 1:1000; for $y$-actin, 1:5000) for $3.5 \mathrm{~h}$. The secondary antibody-HRP 
conjugate was used in 1:2500 dilutions with incubation at $37^{0} \mathrm{C}$ for $1.5 \mathrm{~h}$. The blots were developed by enhanced chemiluminescence technique and $\gamma$ - actin was used as the internal loading control. The loading control bands were developed by stripping and re-probing the membrane with antibody to $y$-actin. The band intensities were compared by image densitometry using Image J software. For A $\beta 42$ immunoblotting, densitometric quantitation was not performed, but equal protein loading in each lane was verified by amido black staining of the membrane in a parallel blot.

For some experiments, synthetic pure $A \beta 42$ was allowed to oligomerize in vitro as described earlier [24]. The oligomerized protein was subjected to SDS-PAGE on $5-15 \%$ gradient gel followed by immunodetection using anti-A $\beta 42$ antibody.

\section{Measurement of $\beta$-secretase activity}

$\beta$-Secretase enzyme activity in the cell lysate was measured by a fluorometric method using commercial kit. Briefly, the cells were harvested, washed thoroughly in phosphate buffered saline and collected by centrifugation. The cell pellet was resuspended in $100 \mu$ l chilled $\beta$ secretase extraction buffer, incubated on ice for $10 \mathrm{~min}$ and then sonicated. An aliquot of the supernatant (10 - 60 $\mu \mathrm{g}$ protein) was mixed with $100 \mu \mathrm{l}$ reaction buffer and 2 $\mu \mathrm{l}$ of synthetic peptide substrate (supplied with the kit), in a total of $200 \mu \mathrm{l}$ reaction volume. The reaction mixture was incubated for $1 \mathrm{~h}$ at $37^{\circ} \mathrm{C}$ in the dark followed by the measurement of the fluorescence intensity $\left(\lambda_{\text {ex }} 345 \mathrm{~nm} /\right.$ $\lambda_{\text {em }} 500 \mathrm{~nm}$ ) keeping appropriate sample and reagent blanks. The specificity of $\beta$-secretase assay in the biological samples was checked by using a specific inhibitor of the enzyme as well as a source of pure enzyme which were provided with the kit.

\section{Measurement of neprilysin activity}

Neprilysin enzyme activity in the cell lysate was measured by a fluorometric method using the substrate $\mathrm{N}$ dansyl-Ala-Gly-D-nitro-Phe-Gly which is an intramolecularly quenched compound [25]. The proteolytic cleavage by neprilysin abolished the intramolecular quenching of Dansyl-fluorescence, and thus the measured fluorescence was an estimate of the enzyme activity. The reaction was carried out in the presence of DL-thiorphan, a specific inhibitor of neprilysin, and the DL-thiorphan sensitive fluorescence reading was used to calculate the neprilysin activity in biological samples. Briefly, the cells were harvested, washed thoroughly in phosphate buffered saline (PBS), and collected by centrifugation. The cell pellet was resuspended in $50 \mathrm{mM}$ Tris buffer, $\mathrm{pH} 8.1$, containing $1 \%$
Triton X100 and then sonicated and centrifuged. An aliquot of the supernatant (50 - $200 \mu \mathrm{g}$ protein) was mixed with $100 \mu$ of the substrate without or with $1 \mathrm{mM}$ DLthiorphan in a total of $200 \mu \mathrm{l}$ reaction volume. The reaction mixture was incubated for $1 \mathrm{~h}$ at $37^{\circ} \mathrm{C}$ followed by the measurement of the fluorescence intensity ( $\lambda$ ex 342 $\mathrm{nm} / \lambda$ em $562 \mathrm{~nm}$ ) keeping appropriate sample and reagent blanks.

\section{Gene expression analysis by quantitative RT-PCR}

Total cellular RNA was prepared by using a commercial kit following the manufacturer's protocol. The concentration and quality of RNA was checked by the ratio of the absorbance at 260 and $280 \mathrm{~nm}$ as well as by electrophoresis. cDNA was synthesized from total cellular RNA using a commercial kit. cDNA template (40 ng) was utilized for amplification and quantitative analysis using a Syber Green based kit in a real-time PCR machine (MiniOpticon, Bio-Rad). The reactions were performed in a $20 \mu \mathrm{l}$ volume with 5 pmol each of forward and reverse primers. Beta-actin was used as the reference gene for normalization during quantification. The efficiency of amplification was also checked, and the gene expression quantified by relative quantitation method following the procedure proposed by Pfaffl [26]. The primer sequences were as follows: APP specific forward primer 5'- AACCAGTGACCATCCAGAAC-3', reverse primer 5'-ACTTGTCAGGAACGAGAAGG-3', $\beta$ secretase specific forward primer 5'-CAGTCCTTCCGC ATCACC-3', reverse primer 5'-TGACAGCAAAGCCA ATTCGT-3', $\beta$-actin forward primer 5'CAGCCATGTACGTTGCTATCCAGG-3', reverse primer 5' - AGGTCCAGACGCAGGATGGCATG-3' .

\section{Measurement of $A_{\beta_{1-42}}$ by Sandwich Elisa}

A $\beta 42$ released in the culture media as well as in cell lysate was analyzed by enzyme-linked immunosorbent assay (ELISA) using a commercial kit following manufacturer's protocol. Synthetic A $\beta 42$ (supplied with the kit) was used to generate a standard curve $(0-1000 \mathrm{pg} / \mathrm{ml})$ for each experiment. An aliquot of the media was diluted in 1:6 ratio in standard dilution buffer (provided with the kit) and used for $\mathrm{A} \beta 42$ measurement. For measurement of intracellular A $\beta 42$, cells were washed with PBS and lysed in $1 \%$ SDS. A $\beta 42$ levels were normalizd and expressed as ng of $A \beta 42$ per $\mathrm{mg}$ of protein.

\section{Estimation of protein}

Samples were assayed for their protein content using the BCA protein assay kit according to the manufacturer's protocol. 


\section{Statistical analysis}

Statistical analysis was conducted using GraphPad Prism v5 software. All data are represented as mean \pm SEM. All experiments were repeated three to six times. Statistical analysis was performed by one way analysis of variance
(ANOVA). These comparisons were followed by posthoc comparisons between groups by means of the Tukey's test. For comparisons between two groups only, paired Student's t-test was performed. All $\mathrm{p}$ values $<0.05$ were considered statistically significant.

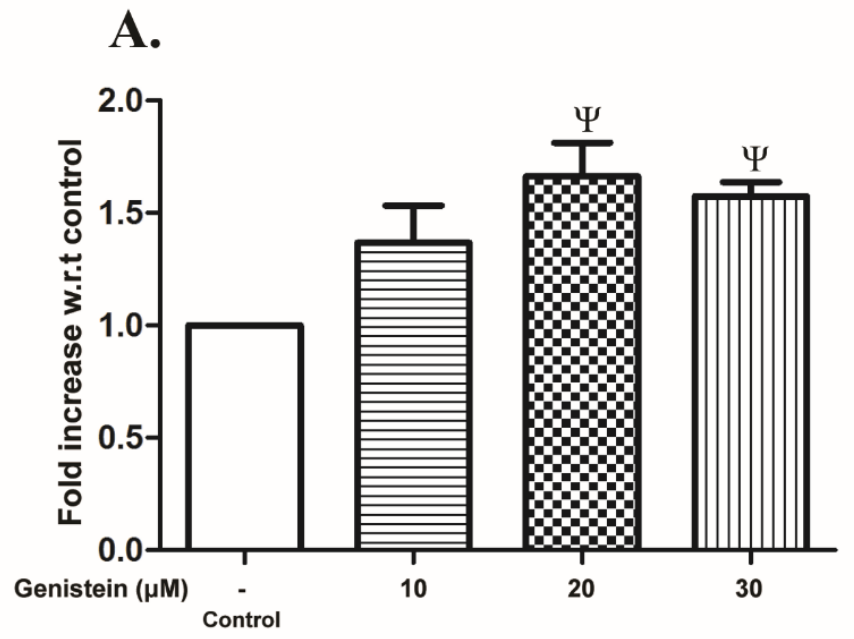

B.

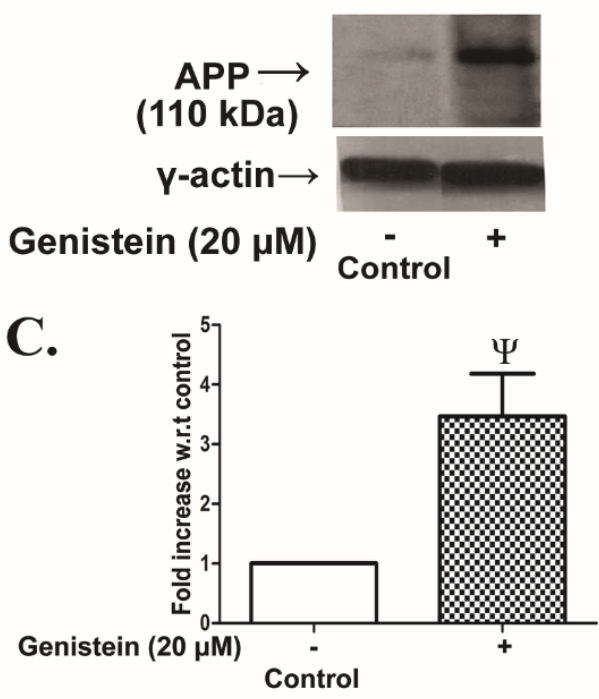

Figure 1. Changes in APP expression by genistein in SHSY5Y cells. SHSY5Y cells were incubated without (control) or with varying concentrations of genistein $(10-30 \mu \mathrm{M})$ for $48 \mathrm{~h}$ followed by the measurement of APP mRNA expressions or intracellular level of APP as described in the MATERIALS AND METHODS. (A) RTqPCR analysis of APP mRNA expression. (B) Representative immunoblot of APP in control or $20 \mu \mathrm{M}$ genisteintreated cells. The two lanes were aligned from different parts of the same blot. C. Densitometric analysis of APP band intensity. The expression level was presented as fold increase over control. The results are the means \pm SEM of 6 observations. Statistically significant, ${ }^{\Psi} \mathrm{p}<0.05$ vs. control.

\section{RESULTS}

\section{Effects of genistein on APP expression}

Results presented in Fig. 1A show that genistein in varying doses caused an increase in APP mRNA expression in SHSY5Y cells which was statistically significant and maximum at $20 \mu \mathrm{M}$ concentration as detected by qPCR. Likewise, the accumulation of APP within SHSY5Y cells was increased conspicuously with respect to control as observed by immunoblotting (Fig. 1B). The APP band intensity was more than 3 times higher in samples obtained from cells treated with $20 \mu \mathrm{M}$ genistein compared to that in untreated control cells (Fig. 1C).

\section{Effect of genistein on $\beta$-secretase expression and activity}

The $\beta$-secretase mRNA expression in SHSY5Y cells was modestly upregulated in the concentration range of $10-$ $30 \mu \mathrm{M}$ of genistein with a maximum of 1.8 fold increase noticed at $20 \mu \mathrm{M}$ concentration with respect to control (Fig. 2A). Likewise, the activity of $\beta$-secretase was also increased by nearly 1.7 fold in SHSY5Y cells after treatment with genistein $(20 \mu \mathrm{M})$ for $48 \mathrm{~h}$ (Fig. 2B). 

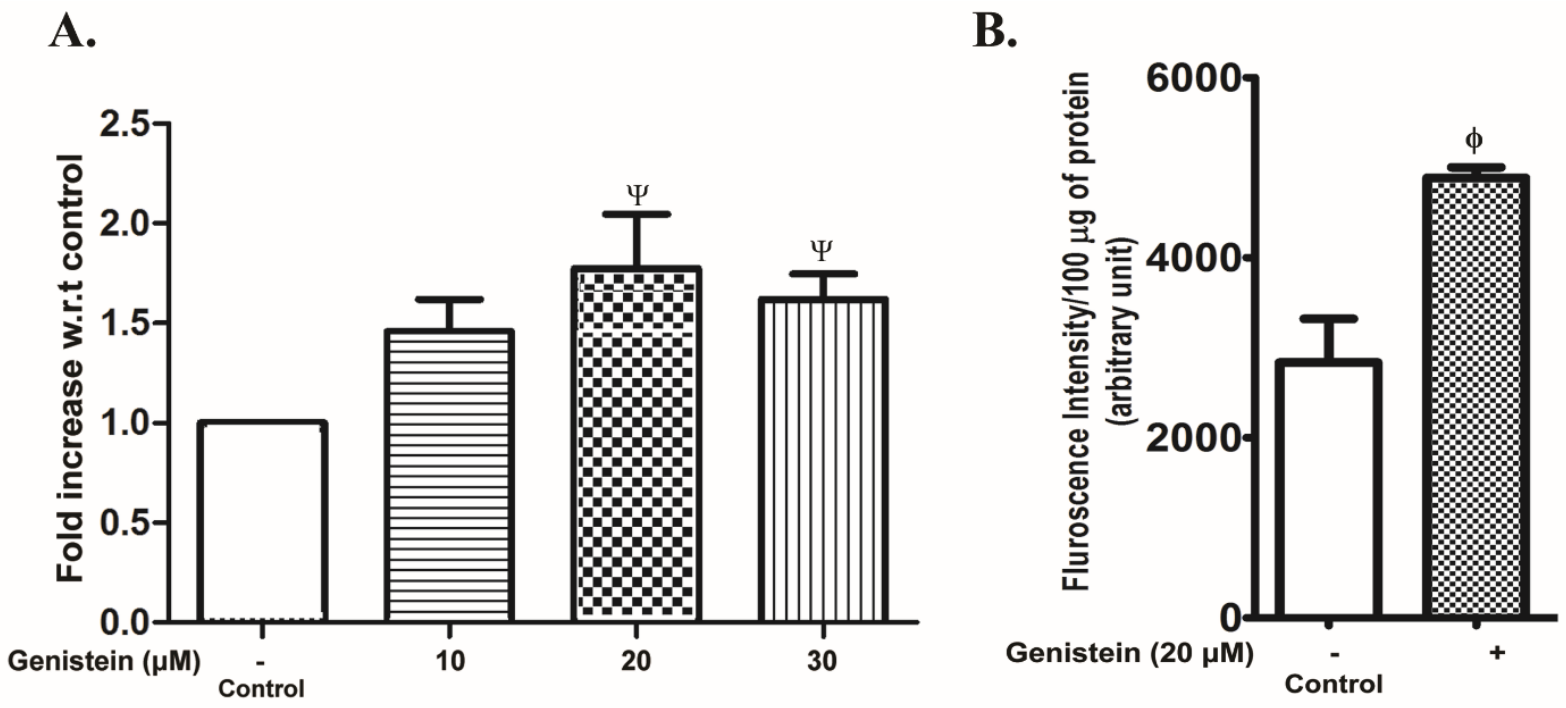

Figure 2. $\beta$-Secretase expression and activity in SHSY5Y cells after exposure to genistein. The SHSY5Y cells were incubated without (control) or with varying concentrations of genistein $(10-30 \mu \mathrm{M})$ for $48 \mathrm{~h}$. The cell lysate was analyzed for $\beta$-secretase mRNA expression or activity as described in the text. (A) RT-qPCR analysis of $\beta$-secretase mRNA expression. The results, expressed as fold increase over control, are the means \pm SEM of 4 observations. Statistically significant, ${ }^{\Psi} \mathrm{p}<0.05$ vs. control. (B) $\beta$-Secretase enzyme activity. The results are the means \pm SEM of 6 observations. Statistically significant, ${ }^{\phi} \mathrm{p}<0.01$ vs. control.

\section{IDE and neprilysin levels in SHSY5Y cells: effect of genistein}

An endogenous expression of IDE was clearly observed in control SHSY5Y cells, but after exposure to $20 \mu \mathrm{M}$ genistein for $48 \mathrm{~h}$ the IDE band was barely detectable by immunoblotting (Fig. 3A). The densitometric analysis (Fig. 3B) shows that the IDE band density decreased by nearly 50\% with respect to control after $48 \mathrm{~h}$ exposure to $20 \mu \mathrm{M}$ genistein. The activity of neprilysin was also diminished by nearly $50 \%$ as compared to the control in SHSY5Y cells after treatment with $20 \mu \mathrm{M}$ genistein for $48 \mathrm{~h}$ (Fig. 3C).

\section{Accumulation of AB42 in SHSY5Y cells after genistein treatment}

In immunoblots for $A \beta 42$ from the extracts of SHSY5Y cells multiple bands ranging from $20-70 \mathrm{kDa}$ and above were clearly visible, which were presumably the oligomers of $\mathrm{A} \beta 42$ (Fig. 4A). The monomer of $\mathrm{A} \beta 42$ was not visible in the blot (Fig. 4A). Similar multiple bands in the blot were also visible when commercially available synthetic $A \beta 42$ was oligomerized in vitro for $72 \mathrm{~h}$ and then analyzed by immunoblotting (Fig. 4C). The commercially available antibody, as stated by the manufacturer, detected amyloid peptides depending on the presence of residues $10-16$.

When SHSY5Y cells were exposed to genistein for $48 \mathrm{~h}$, the intracellular accumulation of $\mathrm{A} \beta 42$ oligomers was remarkably increased as apparent from the multiple intense bands seen on the blot (Fig. 4A). Since multiple bands were observed and the changes after genistein treatment were visibly very conspicuous, no densitometric analysis was performed. The accumulation of A 342 within SHSY5Y cells after genistein treatment was also verified by measuring $A \beta 42$ in cell lysate by ELISA. The A $\beta 42$ content in the lysate of cells treated with $20 \mu \mathrm{M}$ genistein was increased by $40 \%$ with respect to the control (Fig. 5B). Further, the release of $A \beta 42$ in the culture supernatant of the control cells was much higher which was decreased very significantly after genistein treatment of SHSY5Y cells (Fig. 5A). 
A.

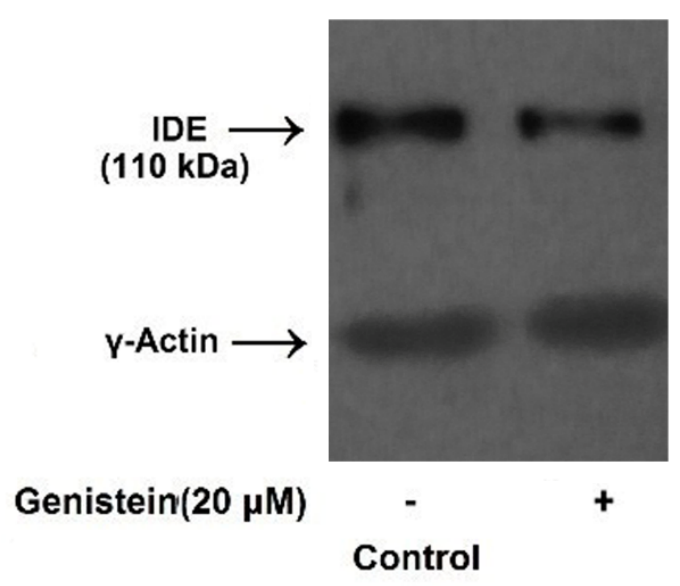

B.

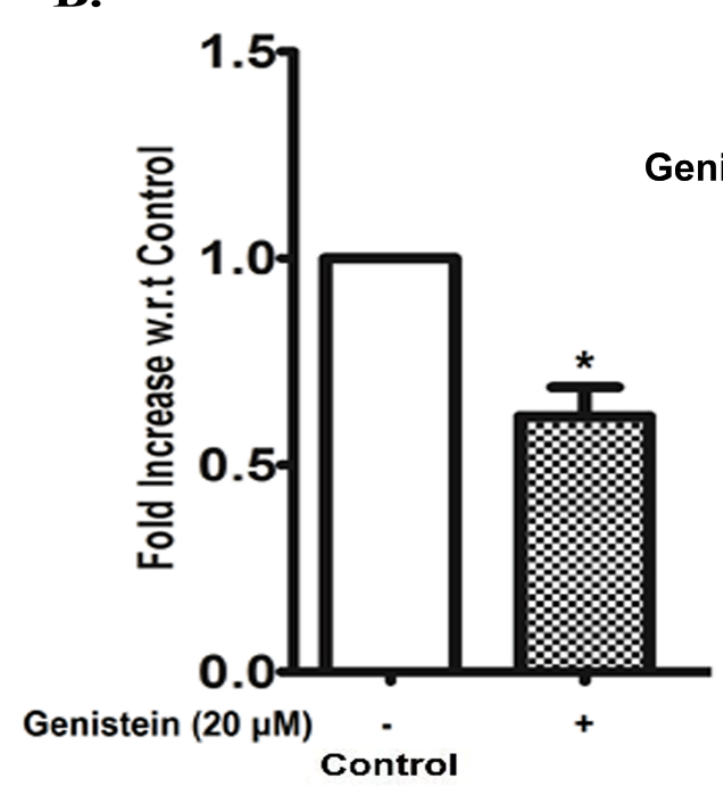

C.

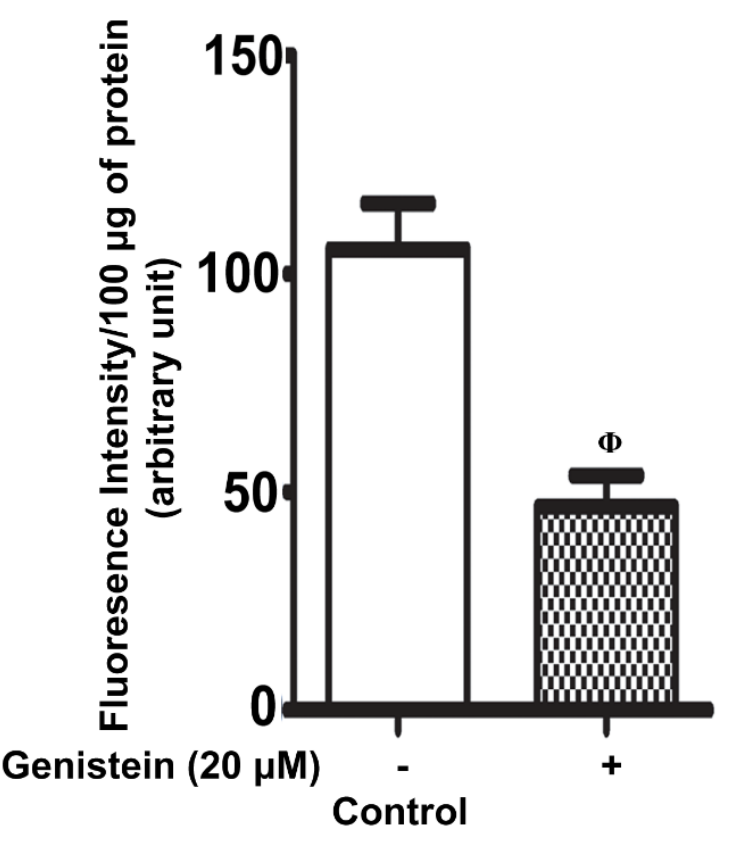

Figure 3. Genistein effect on IDE and neprilysin level in SHSY5Y cells. SHSY5Y cells were grown in the absence (control) or in the presence of genistein $(20 \mu \mathrm{M})$ for $48 \mathrm{~h}$. The cell lysate was analysed for IDE content by immunoblotting using $\gamma$-actin as the loading control or neprilysin enzyme activity as described in the 'MATERIALS AND METHODS'. (A) Representative blot. (B) Densitometric analysis of IDE immunoblots with the band intensity expressed as the fold changes with respect to the control. C. Neprilysin enzyme activity. The results are the means \pm SEM of 6 observations. Statistically significant, ${ }^{*} \mathrm{p}<0.001$ vs. control; ${ }^{\phi} \mathrm{p}<0.01$ vs. control. 


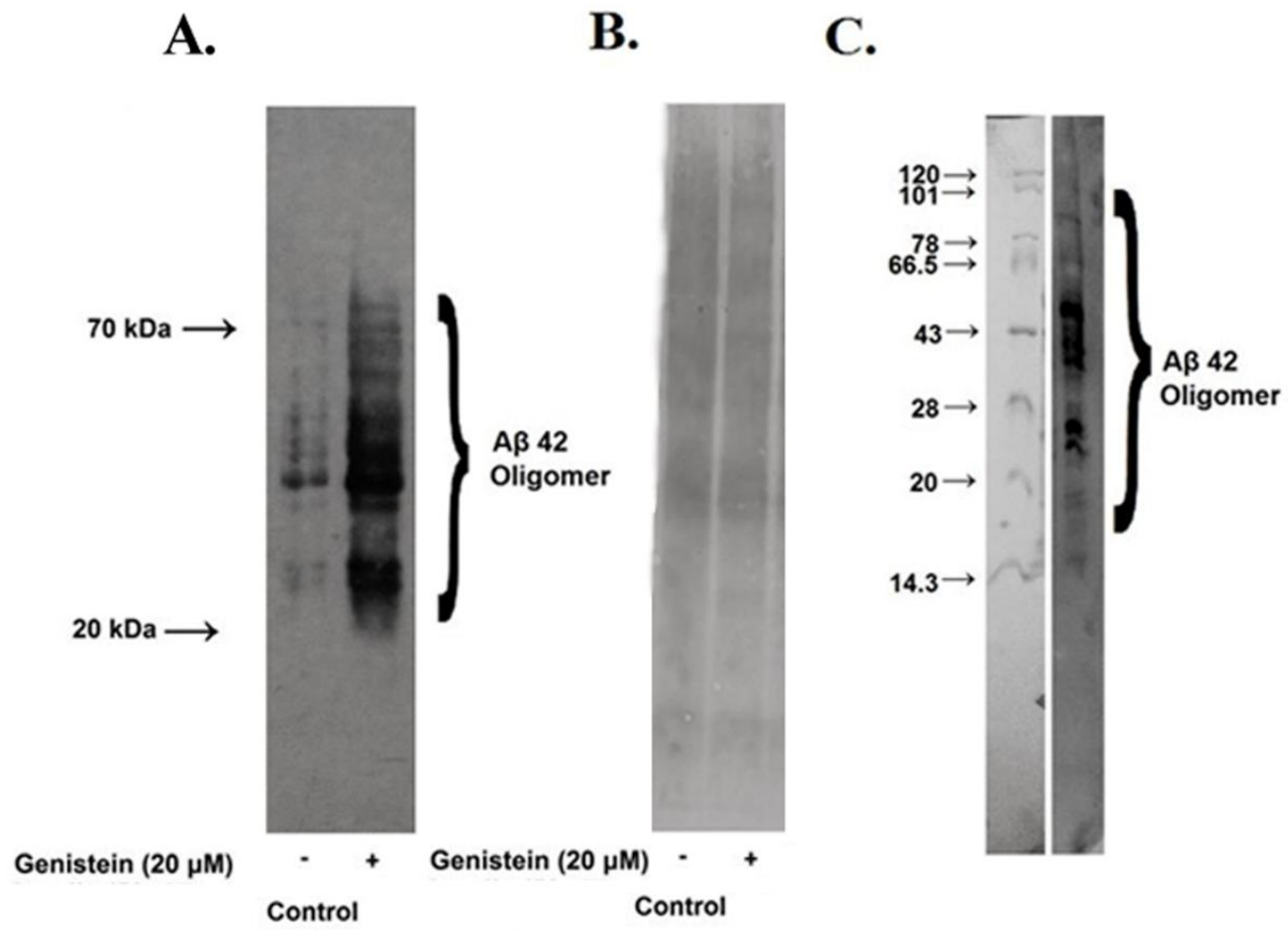

Figure 4. Effect of genistein on Aß42 content of SHSY5Y cells. SHSY5Y cells were incubated without (control) or with $20 \mu \mathrm{M}$ of genistein for $48 \mathrm{~h}$. (A) The cell lysate was analyzed for A $\beta$ oligomers by immunoblotting as mentioned in the text. (B) Amido black stained membrane from a parallel blot. (C) Oligomerized A 342 analyzed by $5-15 \%$ SDS-PAGE followed by immunoblotting.

\section{DISCUSSION}

In the present study, we have clearly demonstrated that genistein has a dose-dependent stimulatory effect on several aspects of amyloid beta peptide synthesis in SHSY5Y cells. For example, the upregulation of APP gene with accumulation of the protein product induced by genistein will provide an oversupply of the substrate for amyloid beta peptide synthesis. More importantly, genistein has increased the mRNA expression and enzyme activity of $\beta$-secretase which could enhance the amyloidogenic pathway of APP processing and increased generation of amyloid beta peptides like $A \beta 42$. There are several studies which have indicated that the increased activity of $\beta$-secretase is well correlated with the accumulation of A $\beta 42$ in aged brain of different species or post-mortem $\mathrm{AD}$ brain $[27,28]$. Thus, the genistein effect causing increased activity of $\beta$-secretase in SHSY5Y cells is highly significant. The decreased levels of A $\beta 42$ degrading enzyme IDE and neprilysin after genistein treatment of SHSY5Y cells are also likely to exacerbate the intracellular accumulation of the toxic peptide. There are several degrading enzymes for $A \beta 42$, but neprilysin and IDE are particularly important in regulating $A \beta 42$ load of the brain $[29,30,31]$. Thus, the combined effect of genistein on APP, $\beta$-secretase, IDE and neprilysin has resulted in the accumulation of $A \beta 42$ in SHSY5Y cells (Fig. 4 and Fig.5). Moreover, the release of A $\beta 42$ from SHSY $5 Y$ cells is also impaired by genistein that will tend to increase the intracellular accumulation of A $\beta 42$ and concomitant toxicity. 
A.

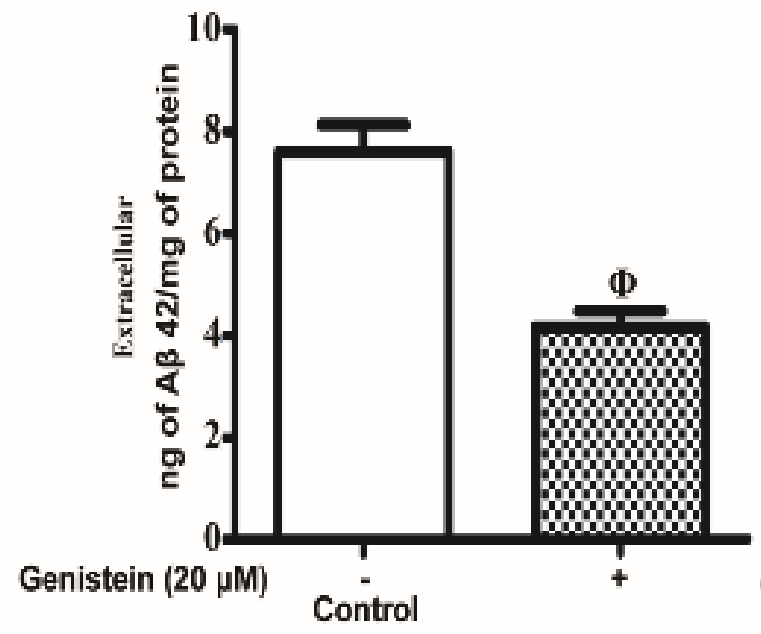

B.

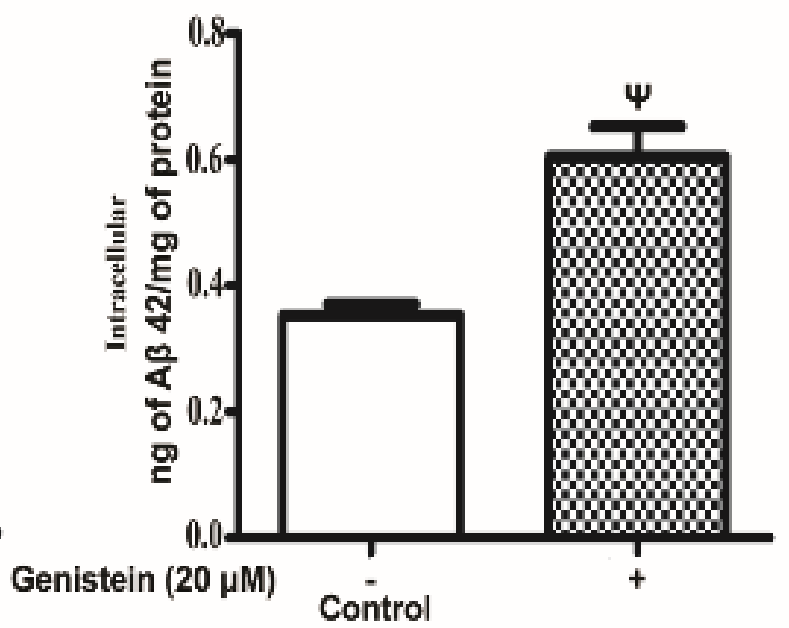

Figure 5. Immunoassay of Aß42. Amyloid $\beta 42$ in the cell lysate as well as that released in the culture medium was measured as described in 'MATERIALS AND METHODS' from control and genistein $(20 \mu \mathrm{M})$ treated SHSY5Y cells. A. Released A $\beta 42$ (extracellular) in culture supernatant. B. Intracellular A $\beta 42$ in cell lysate. The results are the mean \pm SEM of four experimental observations. Statistically significant, ${ }^{\phi} \mathrm{p}<0.01$ vs. control; ${ }^{\Psi} \mathrm{p}<0.05$ vs. control.

In the present study, we have not explored the molecular mechanism of genistein mediated upregulation of APP and $\beta$-secretase or the downregulation of IDE. Given the wide array of cellular alterations induced by genistein in different experimental models, it will be difficult to identify the underlying mechanisms of genistein effects on amyloid beta metabolism at this stage $[16,17,18]$. However, we presume that tyrosine kinase inhibition by genistein interfering with several growth factor signaling pathways may be important in this regard. The downstream toxic effects of the pro-amyloidogenic action of genistein in SHSY5Y cells have not been examined further here, but it is important to point out that a recent study using the same cell line has demonstrated that APP overexpression and A $\beta 42$ accumulation causes mitochondrial dysfunction [32]. Even in the absence of such mechanistic details and despite the fact that present results are obtained in cell line experiments, our data have several significant implications in relation to potential therapeutic benefit of genistein against AD. Although several experimental cell based studies have identified the neuroprotective action of genistein or documented its ability to prevent memory or behavioral deficits in animal models in different conditions, a clinical trial of this compound against $\mathrm{AD}$ should take in to account the multiple ways genistein can affect cellular pathophysiology [7, 8, 13, 33]. In fact, several known effects of genistein such as induction of apoptosis and mitochondrial dysfunction do not support the putative therapeutic effect of genistein against $\operatorname{AD}[34,35]$.
Likewise another study has shown the failure of genistein to protect against amyloid beta peptide induced mitochondrial dysfunction in platelets [36]. Our present results showing an accumulation of A $\beta 42$ in SHSY5Y cells after genistein treatment further pose a question mark on the putative efficacy of this compound against $\mathrm{AD}$. On the other hand, the results of this study tend to support the epidemiological findings linking increased mid-life tofu (rich in genistein) consumption with impaired memory and cognition $[14,15]$. Thus, another obvious implication of this study would be the potential risk of high intake of soybean food products in general population.

It is important to mention here that our results have been obtained with a neuroblastoma cell line, and therefore it is imperative to validate these toxic actions of genistein in suitable experimental models. Further, in this study genistein effect has been observed in a restricted concentration range of $10-30 \mu \mathrm{M}$, which raises the question of its pathophysiological significance. The plasma concentration of genistein is low and varies from nanomolar to low micromolar concentrations depending on the consumption of soybean food products with the diet $[37,38,39]$. However, there is no systematic study of plasma and brain concentrations of genistein or its tissue accumulation during long-term consumption of the pure compound. Thus, the possible pro-amyloidogenic action of genistein, as indicated in this study, during long term treatment with this compound cannot be overlooked especially when the drug is on a clinical trial against AD. 


\section{Acknowledgements}

The work was supported by a grant from the Department of Biotechnology, Govt. of India. GC was supported by a research fellowship from the Council of Scientific and Industrial Research, Govt. of India.

\section{References}

[1] Fukutake M, Takahashi M, Ishida K, Kawamura H, Sugimura T, Wakabayashi K (2000). Quantification of genistein and genistein in soybeans and soybean products. Food Chem Toxicol, 34: 457-61.

[2] Omoni AO, Aluko RE (2005). Soybean foods and their benefits: potential mechanisms of action. Nutr Rev, 63: 272-83.

[3] Yuan B, Wang L, Jin Y, Zhen H, Xu P, Xu Y, Li C, Xu $\mathrm{H}$ (2012). Role of metabolism in the effects of genistein and its phase II conjugates on the growth of human breast cell lines. AAPS J, 14: 329-44.

[4] George J, Banik NL, Ray SK (2010). Genistein induces receptor and mitochondrial pathways and increases apoptosis during BCL-2 knockdown in human malignant neuroblastoma SK-N-DZ cells. J Neurosci Res, 88: 877-86.

[5] Correia SC, Santos RX, Santos MS, Casadesus G, Lamanna JC, Perry G, Smith MA, Moreira PI (2013). Mitochondrial abnormalities in a streptozotocininduced rat model of sporadic Alzheimer's disease. Curr Alzheimer Res, 10: 406-19.

[6] Kreijkamp-Kaspers S, Kok L, Grobbee DE, de Haan EH, Aleman A, Lampe JW, van der Schouw YT (2004). Effect of soy protein containing isoflavones on cognitive function, bone mineral density, and plasma lipids in postmenopausal women: a randomized controlled trial. JAMA, 292: 65-74.

[7] Bagheri M, Joghataei MT, Mohseni S, Roghani M (2011). Genistein ameliorates learning and memory deficits in amyloid $\beta$ (1-40) rat model of Alzheimer's disease. Neurobiol Learn Mem, 95: 270-76.

[8] Baluchnejadmojarad T (2009). The Effect of Genistein on Intracerebroventricular Streptozotocin-Induced Cognitive Deficits in Male Rat. Basic Clin Neurosci, (Autumn), 1: 17-21.

[9] Valles SL, Dolz-Gaiton P, Gambini J, Borras C, Lloret A, Pallardo FV, Viña J (2010). Estradiol or genistein prevent Alzheimer's disease-associated inflammation correlating with an increase PPAR gamma expression in cultured astrocytes. Brain Res, 1312:138-44.

[10] Bang OY, Hong HS, Kim DH, Kim H, Boo JH, Huh K, Mook-Jung I (2004). Neuroprotective effect of genistein against beta amyloid-induced neurotoxicity. Neurobiol Dis, 16: 21-28.

[11] Bagheri M, Rezakhani A, Nyström S, Turkina MV, Roghani M, et al. (2013). Amyloid Beta1-40-induced astrogliosis and the effect of genistein treatment in rat: a three-dimensional confocal morphometric and proteomic study. PLoS ONE, 8: e76526.
Zeng H, Chen Q, Zhao B (2004). Genistein ameliorates beta-amyloid peptide (25-35)-induced hippocampal neuronal apoptosis. Free Radic Biol Med, 36: 180-88.

[13] Viña J. Genistein as a possible treatment for Alzheimer's disease. Valencia, Spain. NCT01982578

[14] White LR, Petrovitch H, Ross GW, Masaki K, Hardman J, Nelson J, Davis D, Markesbery W (2000). Brain aging and midlife tofu consumption. J Am Coll Nutr, 19: 242-55.

[15] Hogervorst E, Sadjimim T, Yesufu A, Kreager P, Rahardjo TB (2008). High tofu intake is associated with worse memory in elderly Indonesian men and women. Dement Geriatr Cogn Disord, 26: 50-57.

[16] Kim H, Peterson TG, Barnes S (1998). Mechanisms of action of the soy isoflavone genistein: emerging role for its effects via transforming growth factor beta signaling pathways. Am J Clin Nutr, 68(6 Suppl): 1418S-25S.

[17] Xie X, Wang SS, Wong TC, Fung MC (2013). Genistein promotes cell death of ethanol-stressed HeLa cells through the continuation of apoptosis or secondary necrosis. Cancer Cell Int, 13:63.

[18] Dang ZC, Audinot V, Papapoulos SE, Boutin JA, Löwik CW (2003). Peroxisome proliferator-activated receptor gamma (PPARgamma) as a molecular target for the soy phytoestrogen genistein. J Biol Chem, 278: 962-67.

[19] Webster NJ, Green KN, Peers C, Vaughan PF (2002). Altered processing of amyloid precursor protein in the human neuroblastoma SH-SY5Y by chronic hypoxia. J Neurochem, 83: 1262-71.

[20] Huang H, Bihaqi SW, Cui L, Zawia NH (2011). In vitro $\mathrm{Pb}$ exposure disturbs the balance between $\mathrm{A} \beta$ production and elimination: the role of $\mathrm{A} \beta \mathrm{PP}$ and neprilysin. Neurotoxicology, 32: 300-06.

[21] Cheung YT, Lau WK, Yu MS, Lai CS, Yeung SC, So KF, Chang RC (2009). Effects of all-trans-retinoic acid on human SH-SY5Y neuroblastoma as in vitro model in neurotoxicity research. Neurotoxicology, 30: 127-35.

[22] Tundo GR, Sbardella D, Ciaccio C, Bianculli A, Orlandi A, Desimio MG, Arcuri G, Coletta M, Marini S (2013). Insulin-degrading enzyme (IDE): a novel heat shock-like protein. J Biol Chem, 288: 2281-89.

[23] Page M \& Thorpe R (2002). Protein blotting by electroblotting. In J.M. Walker (Ed.). The Protein Protocols Handbook (pp. 317-319). New Jersey: Humana Press.

[24] Sinha M, Bhowmick P, Banerjee A, Chakrabarti S (2013). Antioxidant role of amyloid $\beta$ protein in cellfree and biological systems: implication for the pathogenesis of Alzheimer disease. Free Radic Biol Med, 56: 184-92.

[25] Oliveri C, Ocaranza MP, Campos X, Lavandero S, Jalil JE (2001). Angiotensin I-converting enzyme modulates neutral endopeptidase activity in the rat. Hypertension, 38: 650-54.

[26] Pfaffl MW (2001). A new mathematical model for relative quantification in real-time RT-PCR. Nucleic Acids Res, 29: 2002-07.

[27] Fukumoto H, Rosene DL, Moss MB, Raju S, Hyman BT, Irizarry MC (2004). Beta-secretase activity 
increases with aging in human, monkey, and mouse brain. Am J Pathol, 164: 719-25.

[28] Coulson DT, Beyer N, Quinn JG, Brockbank S, Hellemans J, Irvine GB, Ravid R, Johnston JA (2010).

BACE1 mRNA expression in Alzheimer's disease postmortem brain tissue. J Alzheimers Dis, 22: 111122.

[29] El-Amouri SS, Zhu H, Yu J, Gage FH, Verma IM, Kindy MS (2007). Neprilysin protects neurons against Abeta peptide toxicity. Brain Res, 1152: 191-200.

[30] Miller BC, Eckman EA, Sambamurti K, Dobbs N, Chow KM, Eckman CB, Hersh LB, Thiele DL (2003). Amyloid-beta peptide levels in brain are inversely correlated with insulysin activity levels in vivo. Proc Natl Acad Sci U S A, 100: 6221-26.

[31] Wang S, Wang R, Chen L, Bennett DA, Dickson DW, Wang DS (2010). Expression and functional profiling of neprilysin, insulin-degrading enzyme, and endothelin-converting enzyme in prospectively studied elderly and Alzheimer's brain. J Neurochem, 115: 4757.

[32] Stockburger C, Gold VA, Pallas T, Kolesova N, Miano D, Leuner K, Müller WE (2014). A cell model for the initial phase of sporadic Alzheimer's disease. J Alzheimers Dis, 42: 395-411.

[33] Bobba A, Petragallo VA, Marra E, Atlante A (2010). Alzheimer's proteins, oxidative stress, and mitochondrial dysfunction interplay in a neuronal model of Alzheimer's disease. Int J Alzheimers Dis, 2010: 1-11.
[34] Yoon HS, Moon SC, Kim ND, Park BS, Jeong MH, Yoo YH (2000). Genistein induces apoptosis of RPE-J cells by opening mitochondrial PTP. Biochem Biophys Res Commun, 276: 151-56.

[35] Salvi M, Brunati AM, Clari G, Toninello A (2002). Interaction of genistein with the mitochondrial electron transport chain results in opening of the membrane transition pore. Biochim Biophys Acta, 1556: 187-96.

[36] Xu J, Shi C, Li Q, Lam WP, Wai MS, Yew DT (2007). Effects of beta-amyloid peptide and estrogen on platelet mitochondrial function of Sprague-Dawley rats. Platelets, 18: 460-68.

[37] Joshi JV, Vaidya RA, Pandey SN, Agashe S, Chandrasekharan S, Menon SK, Vaidya AD (2007). Plasma levels of genistein following a single dose of soy extract capsule in Indian women. Indian J Med Res, 125: 534-41.

[38] Klein CB, King AA (2007). Genistein genotoxicity: critical considerations of in vitro exposure dose. Toxicol Appl Pharmacol, 224: 1-11.

[39] Wiseman H, Casey K, Bowey EA, Duffy R, Davies M, Rowland IR, Lloyd AS, Murray A, Thompson R, Clarke DB (2004). Influence of 10 wk of soy consumption on plasma concentrations and excretion of isoflavonoids and on gut microflora metabolism in healthy adults. Am J Clin Nutr, 80: 692-99. 